\title{
Analysis on the Innovation to Sculpting with the Aid of 3D Digital Technology
}

\author{
Ning Wang \\ Guangdong industry technical college \\ Guangdong Guangzhou 510300 \\ e-mail: 103817165@qq.com \\ *Corresponding author: Wang Ning
}

\begin{abstract}
Digital age provokes huge revolution on realm of art. Integration of digital technology and art design provides more abundant manifestation pattern and communication carrier for design of statuary art. This paper introduced innovation process of computer technology; sculpture development based on $3 \mathrm{D}$ software technology application and application of current digitization sculpture and discussed the effect of computer technology innovation to sculpture and its future development trend.
\end{abstract}

Keywords—3D ; Digital technology; sculpting; Innovation

\section{INTRODUCTION}

Human society steps into digitization age with the rapid development of information technology [1]. Meanwhile, sculpture realm also occurs significant change. More and more works created based on digital technology appear. That is, digitization sculpture (or termed as sculpture based on $3 \mathrm{D}$ software).

Digitization sculpture is the cross of art and computer science and the subject integrating sensibility and reason [2]. Digital art at home and abroad are all in starting stage because of its youth. Compared to traditional sculpture technique, sculpture based on $3 \mathrm{D}$ software occurs significant changes on material and art form presentation [3-6]. Sculpture creation based on $3 \mathrm{D}$ software plays important function on statuary realm especially environment sculpture because computer sculpture creation is characterized by virtuality, interaction and high efficiency. Freedom and high efficiency of creation technique and diversity of creation platform change sculpture creation and promote the communication between public and art.

\section{DEVELOPMENT OVERVIEW OF COMPUTER}

\section{TECHNOLOGY AND SCUlPTURE BASED ON 3 D SOFTWARE}

\section{A. Innovation process of computer technology}

From the first generation computer, improvement of computer basic components promotes technology innovation and permeates into different realms of society, as shown in "Table. 1".
TABLE I. DEVELOPMENT PROCESS OF COMPUTER TECHNOLOGY[7-8]

\begin{tabular}{|c|c|c|c|}
\hline $\begin{array}{c}\text { Generatio } \\
\mathbf{n}\end{array}$ & $\begin{array}{l}\text { Main basic } \\
\text { component }\end{array}$ & Characteristic & Use \\
\hline $\begin{array}{c}\text { First } \\
\text { generation } \\
\text { computer }\end{array}$ & $\begin{array}{l}\text { Electronic } \\
\text { valve }\end{array}$ & $\begin{array}{l}\text { Large volume, slow } \\
\text { arithmetic speed }\end{array}$ & $\begin{array}{l}\text { Mainly used for } \\
\text { improving } \\
\text { computation speed } \\
\text { of computer }\end{array}$ \\
\hline $\begin{array}{l}\text { Second } \\
\text { generation } \\
\text { computer }\end{array}$ & Transistor & $\begin{array}{l}\text { Power consumption } \\
\text { and cost decrease and } \\
\text { arithmetic speed } \\
\text { constantly improve }\end{array}$ & $\begin{array}{c}\text { Widely applied in } \\
\text { science, business } \\
\text { and management } \\
\text { realm }\end{array}$ \\
\hline $\begin{array}{l}\text { Third } \\
\text { generation } \\
\text { computer }\end{array}$ & $\begin{array}{l}\text { Integrated } \\
\text { circuit }\end{array}$ & $\begin{array}{l}\text { Computer arithmetic } \\
\text { speed improve }\end{array}$ & $\begin{array}{c}\text { Meet relative } \\
\text { operation } \\
\text { requirement to some } \\
\text { extend }\end{array}$ \\
\hline $\begin{array}{c}\text { Four } \\
\text { generation } \\
\text { computer }\end{array}$ & $\begin{array}{l}\text { Large scale } \\
\text { integrated } \\
\text { circuit }\end{array}$ & $\begin{array}{l}\text { Professional staff are } \\
\text { not needed to do } \\
\text { master operation on } \\
\text { computer and branch } \\
\text { staff can rapidly } \\
\text { fulfill relative } \\
\text { operation }\end{array}$ & $\begin{array}{l}\text { Meet realms of } \\
\text { society }\end{array}$ \\
\hline $\begin{array}{c}\text { Fifth } \\
\text { generation } \\
\text { computer }\end{array}$ & $\begin{array}{c}\text { Super- } \\
\text { large-scale } \\
\text { integrated } \\
\text { circuit }\end{array}$ & $\begin{array}{l}\text { Production efficiency } \\
\text { and working } \\
\text { efficiency are all } \\
\text { relatively improved }\end{array}$ & Realms of society \\
\hline
\end{tabular}

B. Development history of sculpture applied $3 \mathrm{D}$ technology

Sculpture creation based on $3 \mathrm{D}$ software is the specific statuary creation means since 21 century. Statuary creation method in early stage changed with the constant innovation of computer technology, as shown in Table. 2:

\section{CURRENT SituAtion OF Digitization Sculpture APPLICATION}

Compared to traditional sculpture expression, digitization sculpture provides efficient and beneficial suggestions for sculpture from material selection to structure and mechanics. First, statuary material turned from clay sculpture or direct material to virtual form for modeling exploration. Stimulation of different materials in $3 \mathrm{D}$ software can provide certain reference for reality material selection. 
Second, efficient calculation capacity provides accurate and detailed data analysis for construction of sculpture works.

\section{TABLE II. DEVELOPMENT HISTORY OF SCULPTURE BASED ON 3 D} SOFTWARE TECHNOLOGY

\begin{tabular}{|c|c|}
\hline Time & Characteristics \\
\hline $\begin{array}{c}1960 \\
\mathrm{~S}\end{array}$ & $\begin{array}{c}\text { New media art with digital technology as the core } \\
\text { gradually developed. }\end{array}$ \\
\hline $\begin{array}{c}1970 \\
\mathrm{~s}\end{array}$ & $\begin{array}{l}\text { With the further development of computer technology, } \\
\text { new media art and filmdom developed in the period of } \\
\text { initial development of computer picture and } 3 \mathrm{D} \text { computer. }\end{array}$ \\
\hline $\begin{array}{c}1980 \\
\mathrm{~S}\end{array}$ & $\begin{array}{l}\text { Personal computer developed in high speed: lots of digital } \\
\text { art design software was born and grew rapidly. } \\
\text { Development of } 3 \mathrm{D} \text { print technology laid the foundation } \\
\text { for the combination of } 3 \mathrm{D} \text { software technology and } \\
\text { sculpture creation }\end{array}$ \\
\hline $\begin{array}{c}1990 \\
\text { s }\end{array}$ & $\begin{array}{l}\text { Internet appeared: } 3 \mathrm{D} \text { software such as Aotodesk and } \\
\text { 3DSMAX appeared and entered into computer art design } \\
\text { realm. It made sculpture creation based on } 3 \mathrm{D} \text { software } \\
\text { had a new development. }\end{array}$ \\
\hline $\begin{array}{c}2000 \\
s\end{array}$ & $\begin{array}{l}3 \mathrm{D} \text { software upgraded the version. Plug-in supplement } \\
\text { provided broad space for its development. } 3 \mathrm{D} \text { printing } \\
\text { rapid prototyping technology were more widely applied. }\end{array}$ \\
\hline
\end{tabular}

So far, digitization sculpture can be mainly divided into the following application means:

- Sequence sense statuary creation: a certain number of units are applied in $3 \mathrm{D}$ software for regular permutation and combination in space, which can make people feel rhythmical and rhythm sense on the vision [2], as shown in "Fig. 1".

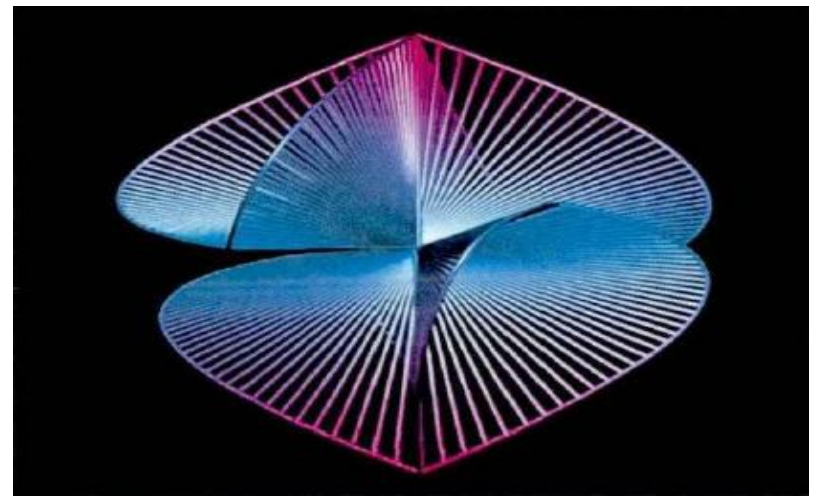

Fig. 1. Sequence sense statuary creation

- Dynamic sense statuary creation: unstable tendency and imbalance of power sense of sculpture modeling make people feel kinesthesia on the vision and mentality [2], as shown in "Fig. 2".

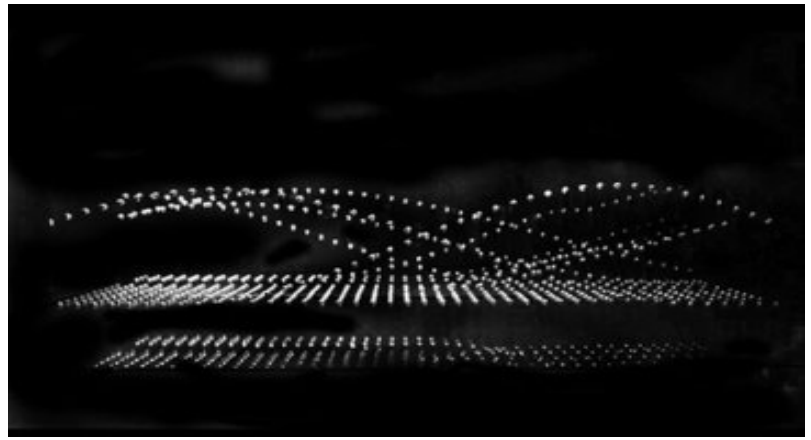

Fig. 2. Dynamic sense statuary creation

- Geometric sense sculpture creation: it is created by combination and change of basic geometric forms. It is usually realized by Boolean operation. The common technique is the adding or subtracting of forms, which make people feel stable substantive sense [2], as shown in "Fig. 3" and "Fig. 4".

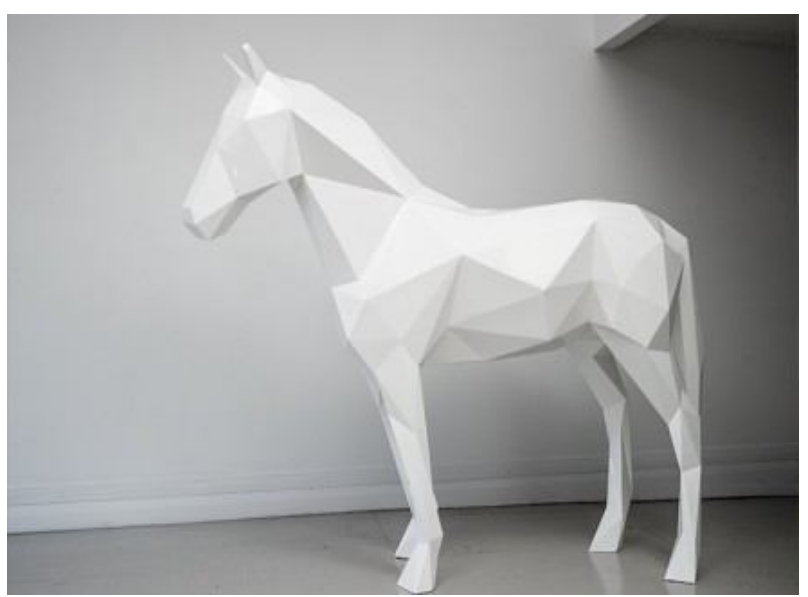

Fig. 3. Geometric animal sculpture

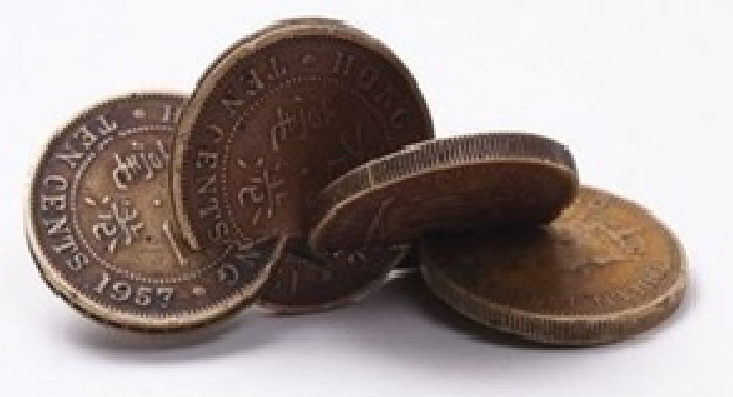

Fig. 4. Geometric coin sculpture

- Emphasis of structural sculpture creation: change of sculpture construction prescribes a limit to modeling. Emphasis of structural sculpture can be further divided into regular structural sculpture and nonregular structural sculpture [2]. Regular structural 
sculpture creation refers to regular connection mode between structural units and rhythmical sense on the vision in overall constitution mode of sculpture "Fig. 5". Otherwise, non regular and random structural sculpture is non regular sculpture creation with stronger sensibility. It need proper control. Otherwise, It would be disordered "Fig. 6".

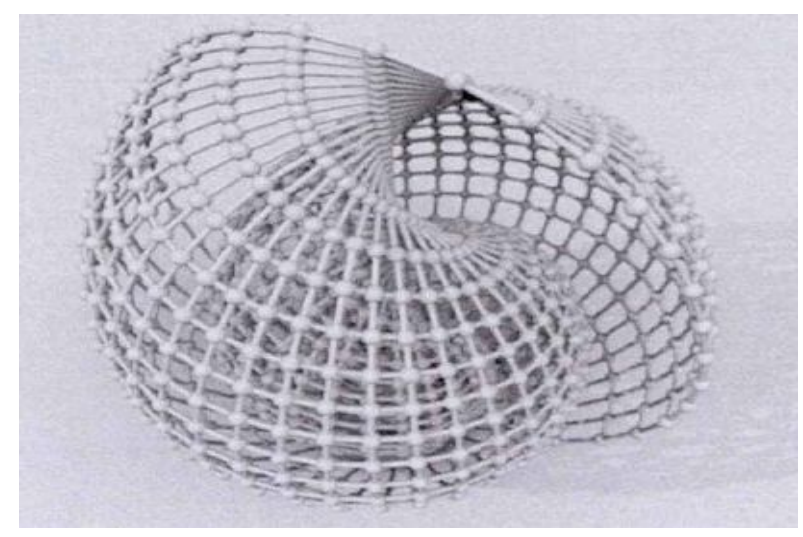

Fig. 5. Regular structural sculpture

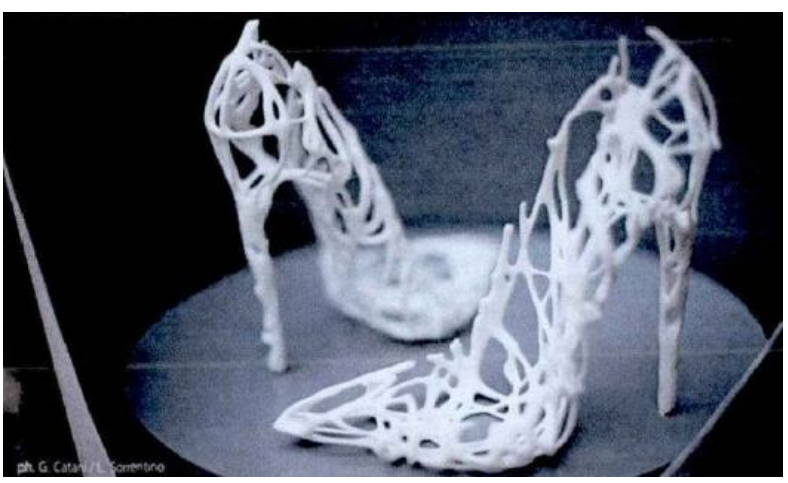

Fig. 6. Non regular structural sculpture

\section{IMPACt AND EFFECT Of Digitization Statuary ART}

- Development and wide application of information technology combine and balance rational science and technology and perceptual artistic designing [9]. Its huge effect and impact have affected people's life and environment.

- Digitization sculpture provides bran-new art creation technique and pattern. It overcomes drawbacks of lots of manpower and manual labor in traditional creation techniques to some extent and avoids irreversibility of traditional creation process, which makes expression platform of creators become more free and diverse [10-11].

- Digitization sculpture enriches manifestation pattern of art and provides bran-new visual and artistic enjoyment [10]. Digitization sculpture can integrate voice frequency, picture and words, which enrich infection and influence of works.
- Application of digitization sculpture changes traditional role observation pattern and existing mode [12-14]. In virtual space, artists sometimes propose unordered picture to inspire the potential creativity of people when creating. Sculpture exists in form of number. Accuracy and modifiability of data are applied for repeated operation and storage on sculpture.

\section{Challenge of Digitization Sculpture}

Development of digitization is not casual. However, it is still a new problem for the current sculpture realm. Most sculptors have limited understanding on digitization sculpture. It mainly has the following reasons:

- Digitization sculpture involves many science and technology problems. Compared to traditional sculpture realm, digitization sculpture has significant difference on creation, carrying, communication, appreciation and judgment. Its knowledge update exists certain challenge for traditional sculptors and sculpture critics.

- Traditional sculpture concept obstacle. First, change of sculpture medium challenges our receptivity and comprehension to sculpture. Second, digitization sculpture weakens visual reality sense that is emphasized by traditional sculpture.

- Space problem. Space understanding of digitization sculpture has broken away from filed domain and occasion. Virtuality of space is new realm for sculpture. And we are not familiar with it.

\section{DEVElopment TREND OF Digitization SCULPTURE}

\section{A. Imitation of interaction of digital art}

Sculpture changes one-way communication and acceptance pattern. Receptors can be creator when participating. It highlights democratization and equality consciousness of sculpture and promotes interaction.

\section{B. Revolution of creation means and communication mode of art}

Virtualized creation means make works have reversibility and high efficiency, provide diversified presentation platform for art creators and promote revolution of creating habit and mode.

\section{Deeper communication of public and art}

Digitization sculpture gradually changes new demand and standard of public for aesthetic. Art appreciation pattern transforms. The boundary between art and technology becomes vague. But the combination of art maturity and technology involution becomes closer. Popularization and diversification close the communication between people and art. 


\section{CONCLUSION}

Digitization sculpture is created on computer platform based on some software. Advance with time of art is inevitable development process [15]. Sculpture developed from traditional sculpture creation to current digitization sculpture. Innovation of computer technology promotes revolution of creation technique and presentation form of sculpture in different degrees and presents freedom and high efficiency of digitization sculpture technique, diversification of creation platform and naturalization and emotion of interactive process.

Computer brings unprecedented revolution for sculpture. Digitization sculpture breaks traditional observation and visual pattern. This paper discussed the conflict, effect and challenge of digitization sculpture and analyzed trend and digitization development in the future based on the revolution research on computer technology innovation and digitization sculpture and status analysis of current digitization sculpture application.

\section{REFERENCES}

[1] Wang He. Effect of digital media technology to modern design art. Science \& Technology for China's Mass Media, (12): 31-32. 2011.

[2] Li Xinlun. Plastic arts and digitization. Beijing: Central Academy of Fine Arts, 2013.

[3] Kong Yuan. Simple analysis of development trend of computer technology. Electronic Production, (6): 88, 2014.

[4] Sun Zhenhua. Sculpture of digital age. Sculpture, (1): 39-41. 2014.

[5] Shen Tao. Discussion on impact and penetration of digital sculpture technology to traditional sculpture. Art Observation, (5): 109, 2013.

[6] Deng Wei. Status analysis of digital sculpture development. Art Panorama, (5): 109, 2013.

[7] Yu Jianhui. Computer sculpture art. Sculpture, (3): 46-47. 2003.

[8] Hu Haiying. Reformation and application of computer technology in new period. Electronic Technology \& Software Engineering, (5): 171. 2014.

[9] Yu Zizhen, Wang Shaojun. Unique vision of combination of science and art - the beauty of digital art and design. Science \& Art. Communication of Science \& Culture in digital age - Collected paper of 2012 Science \& Art Seminar. 2012.

[10] Hong Qinxue, Ruan Ruyan. Simple discussion on the effect of digital art to art design. Jingdezhen Comprehensive College Journal, (2): 108-109. 2010.

[11] Liu Lei, Xiong Shuijin. Simple discussion on reformation and application of computer technology in new age. Computer CD Software \& Application, (23): 305-306. 2013.

[12] Jiang Shuya. Effect and revolution of digital art to environmental art design. Design, (2): 136. 2012.

[13] Peng Haoliang. Effect of digital art age to interaction design. Public Literature, (4): 78. 2012.

[14] Chen Cheng. Primary exploration of development and effect of digital art in art design. Jilin Education College Journal (Midmonth), 29(2): 125-126. 2013.

[15] $\mathrm{Yu}$ Bo. Discussion on the constitution of digital art design value. China: China Academy of Art, 2008. 